\title{
Staatsimmuniteit van executie: beslagmogelijkheden voor crediteuren na de herfstarresten van de Hoge Raad (2016)
}

\author{
Prof. dr. C.M.J.Ryngaert*
}

In de herfst van 2016 heeft de Hoge Raad een aantal belangwekkende arresten inzake de staatsimmuniteit van executie gewezen, ${ }^{1}$ waarin hij met name het vermoeden bevestigt dat de vreemde staat immuniteit geniet in zowel executoriale als conservatoire beslagprocedures. De schuldeiser kan dit vermoeden weerleggen door te bewijzen dat de beoogde beslagobjecten gebruikt worden of bestemd zijn voor andere dan publieke doeleinden. ${ }^{2}$ Een en ander doet de vraag rijzen in hoeverre de schuldeiser de volgens de Hoge Raad op hem rustende stelplicht en bewijslast kan effectueren, en bijgevolg in hoeverre hij nog executiemaatregelen kan nemen ten aanzien van goederen van vreemde staten.

In deze bijdrage situeer ik de arresten van de Hoge Raad in een internationaalrechtelijke context (paragraaf 1). Vervolgens voer ik aan dat de Hoge Raad de op de schuldeiser rustende stelplicht praktisch werkbaar heeft willen houden teneinde de bescherming die de restrictieve immuniteitsleer aan de schuldeiser hoort te bieden niet illusoir te maken (paragraaf 2). Ik argumenteer vervolgens dat de schuldeiser in het kader van de herfstarresten ermee kan volstaan aannemelijk te maken dat de onmiddellijke bestemming of het onmiddellijke gebruik van de opbrengsten uit de schuldvordering niet-publiek of niet-soeverein van aard zijn (paragraaf 3 ). Ten slotte argumenteer ik dat de algemene gewoonterechtelijke regels inzake staatsimmuniteit niet onverkort gelden voor een bijzondere categorie van executieprocedures, namelijk deze die betrekking hebben op arbitrale vonnissen. Door met arbitrage in te stemmen wordt de betrokken vreemde staat geacht afstand te heb-

Prof. dr. C.M.J. Ryngaert is hoogleraar internationaal publiekrecht aan de Universiteit Utrecht.

1. HR 30 september 2016, ECLI:NL:HR:2016:2236, RvdW 2016, 1031; HR 14 oktober 2016, ECLI:NL:HR:2016:2371, RvdW 2016, 1054 en HR 14 oktober 2016,ECLI:NL:HR:2016:2354, RvdW 2016, 1056.

2. Ik heb de arresten in detail besproken met mijn co-auteur in C. Ryngaert en A. Jongbloed, 'De beslagrechtelijke immuniteit van vreemde staten na de herfstarresten van de Hoge Raad (2016)', Beslag en Executie in de Rechtspraktijk 2016 afl. 5/6, p. 19-24. Ik verwijs dan ook naar dit artikel voor een kritische lezing van de arresten. In onderhavig artikel verken ik meer specifiek de beslagmogelijkheden die de Hoge Raad de schuldeiser nog laat. ben gedaan van de immuniteit waarop hij eventueel recht heeft (paragraaf 4). Ik concludeer ten slotte dat de Hoge Raad de deur niet volledig heeft dichtgedaan voor schuldeisers die beogen beslag te leggen op goederen van vreemde staten (paragraaf 5).

Methodologisch is mijn betoog gebaseerd op een analyse van de relevante staatspraktijk, waarop de internationaalgewoonterechtelijke immuniteit van executie is gebaseerd. Ik baseer mij daarbij met name op buitenlandse rechtspraak waar vergelijkbare kwesties zijn gerezen.

\section{Staatsimmuniteit van executie in het volkenrecht}

Het internationale recht van de staatsimmuniteit maakt een onderscheid tussen staatsimmuniteit van rechtsmacht (jurisdictie) en staatsimmuniteit van executie. Beide modaliteiten van staatsimmuniteit zijn, althans in theorie, onderworpen aan aparte juridische regimes. Deze regimes zijn gecodificeerd in het VN-Verdrag inzake de Jurisdictionele Immuniteiten van de Staat (2004). Weliswaar is dit verdrag nog niet in werking getreden bij gebrek aan voldoende ratificaties, maar de verdragsbepalingen zijn grotendeels van gewoonterechtelijke aard. ${ }^{3}$

Staten genieten in beginsel immuniteit van de rechtsmacht van nationale rechtbanken, zij het dat een groot aantal uitzonderingen tegenwoordig is aanvaard, met name in gedingen naar aanleiding van commerciële transacties. ${ }^{4}$ Ingeval nationale rechtbanken hun rechtsmacht op basis van deze uitzonderingen hebben vastgesteld, de staat afstand van immuniteit heeft gedaan, of een scheidsgerecht zijn rechtsmacht heeft vastgesteld, én een vonnis tegen de vreemde staat is gewezen, rijst in een tweede fase de vraag of dwangmaatregelen kunnen

3. Zie voor een gedetailleerde commentaar, met inbegrip van de gewoonterechtelijke status van de respectieve regels: R. O’Keefe, C.J. Tams \& A. Tzanakopoulos (red.), The United Nations Convention on Jurisdictional Immunities of States and Their Property:A Commentary, Oxford: Oxford University Press 2013. Voor een kortere bespreking: D.P. Stewart, 'The Immunity of State Officials Under the UN Convention on Jurisdictional Immunities of States and Their Property', Vanderbilt Journal of Transnational Law 2011, afl. 1, p. 1047-1071.

4. Art. 5en 11-17 VN-Verdrag. 
worden genomen tegen de vreemde staat die het vonnis niet naleeft. ${ }^{5}$ Dit is de vraag naar de immuniteit van executie. In de brede zin van het woord betreft immuniteit van executie overigens zowel uitvoerend als conservatoir beslag: de relevante immuniteitsregels gelden zodra dwangmaatregelen tegen de vreemde staat worden overwogen, zelfs voor een rechtbank zijn rechtsmacht heeft vastgesteld. ${ }^{6}$

De mogelijkheden om dwangmaatregelen te nemen tegen vreemde staten zijn op het eerste gezicht beperkter dan de mogelijkheden om rechtsmacht over deze staten vast te stellen. Immuniteit van executie wordt daarom wel eens als het laatste bastion van staatsimmuniteit bestempeld. ${ }^{7}$ Omdat de regimes van immuniteit van executie en immuniteit van rechtsmacht van elkaar verschillen, is het niet onmogelijk dat de staat geen beroep op immuniteit van rechtsmacht toekomt, bijvoorbeeld omdat de zaak een arbeidsgeschil betrof, ${ }^{8}$ terwijl hij zich toch kan beroepen op zijn immuniteit van executie, bijvoorbeeld omdat de goederen waarop de schuldeiser beslag wenst te leggen een soevereine, niet-commerciële bestemming hebben. ${ }^{9}$

In een aantal landen bestaat, op basis van nationale wetgeving, overigens wel een zeker parallellisme tussen immuniteit van rechtsmacht en executie. Zo heeft een Canadese rechtbank gesteld dat uit de afwezigheid van immuniteit van rechtsmacht voor commerciële activiteiten voortvloeit dat er ook geen immuniteit van executie is:

'Where there is no immunity from suit, there should be no immunity from execution. In other words, if an agency of a foreign state is (...) not immune from the jurisdiction of a court because the proceedings in question relate to a commercial activity, then its property cannot be immune from attachment and execution.' 10

5. VN-Commissie voor Internationaal Recht, Draft articles on Jurisdictional Immunities of States and Their Property, with commentaries, Yearbook of the International Law Commission, 1991, vol. II, Part Two, p. 56.

6. Conservatoir beslag wordt beheerst door art. 18 van het VN-Verdrag, executiebeslag door art. 19. In de herfstarresten heeft de Hoge Raad beslist dat art. 18 het gewoonterecht niet weerspiegelt voor zover het conservatoir beslag onmogelijk maakt met betrekking tot goederen die bestemd zijn voor andere dan publieke doeleinden (met andere woorden dat conservatoir en executiebeslag aan hetzelfde juridische regime onderworpen zijn). Zie meer in detail over het bestemmingscriterium: paragraaf 3 van deze bijdrage.

7. Ibid.

8. Zie de uitzondering in art. $11 \mathrm{VN}-$ Verdrag.

9. Art. $19 \mathrm{VN}-$ Verdrag.

10. Canficorp Overseas Projects Ltd., and Intrafina Ltd., Demanderesses/ Requérantes, vs Asbestos Plastic Industries, Public Enterprise et al, and Rafidain Bank of Iraq, and Republic of Iraq, and Central Bank of Iraq, and Rasdhid Bank, Défenderesses, and Royal Bank of Canada, Tiercesaisie/intimée, Province de Québec, District de Montréal, No. 500-05-009071-935, 7 maart 1995, p. 22. 1995 CarswellQue 408. Zie voor het toepasselijke Canadese recht: Article 12 (2) State Immunity Act (Canada) (R.S.C. 1985 c. S-18) ('Subject to subsection (3), property of an agency of a foreign state is not immune from attachment and execution and, in the case of an action in rem, from arrest, detention, seizure and forfeiture, for the purpose of satisfying a judgment of a court in any proceedings in respect of which the agency is not immune from the jurisdiction of the court by reason of any provision of this Act.').
In de Verenigde Staten wordt formeel een onderscheid gemaakt tussen immuniteit van rechtsmacht en executie, maar de uitzonderingen op de immuniteit van executie zijn relatief ruim opgevat, ${ }^{11}$ waardoor de kans reëel is dat de schuldeiser een in zijn voordeel gewezen vonnis ook daadwerkelijk zal kunnen afdwingen. De ruime formulering van uitzonderingen op de immuniteit van executie in de Amerikaanse wetgeving heeft recent aanleiding gegeven tot een door Iran tegen de VS aangespannen procedure voor het Internationaal Gerechtshof. $^{12}$

Algemeen wordt in ieder geval aanvaard dat, hoewel de immuniteit van executie als breder dan de immuniteit van rechtsmacht wordt gezien, deze immuniteit niet absoluut is: (slechts) goederen die ten dienste staan aan een publieke taak van een vreemde staat genieten immuniteit van executie. ${ }^{13}$ In de Engelstalige literatuur en jurisprudentie wordt in dat kader wel de term 'sovereign purpose', 'public purpose', of 'government non-commercial purpose' gehanteerd. ${ }^{14}$ Dit betekent dat in beginsel (slechts) goederen die bestemd of benodigd zijn voor de uitoefening van klassieke overheidstaken onder de staatsimmuniteit van executie vallen. Zo besliste het Internationaal Gerechtshof in de Jurisdictional Immunities Case (2012) dat een eigendom van de Duitse staat immuniteit van executie genoot omdat deze '[was] being used for governmental purposes that are entirely non-commercial, and hence for purposes falling within Germany's sovereign functions'. ${ }^{15}$ Sommige staten, zoals Italië, gebruiken in dit kader het aan de immuniteit van rechtsmacht ontleende criterium van acta jure imperii, waarbij dan ook jure gestionis-handelingen (privaatrechtelijke of beheershandelingen) geen immuniteit toekomt. $^{16}$

Artikel 21 van het hoger genoemde VN-Verdrag somt een aantal goederen op die binnen deze term vallen en waarop een schuldeiser derhalve geen beslag mag leggen (bijvoorbeeldeigendommen van de centrale bank, militaire eigendommen, cultureel erfgoed). Anderegoederen zijn overeenkomstig artikel 19 van het $\mathrm{VN}$-verdrag slechts voor beslag vatbaar indien

11. 28 U.S.C. section 1610.

12. Iran voert aan dat de VS de immuniteit van executie van Iran schendt (op basis van een Verdrag uit 1955), omdat het dwangmaatregelen toelaat ten aanzien van staten, zoals Iran, die als 'state sponsors of terrorism' worden beschouwd. Internationaal Gerechtshof 14 juni 2016, Certain Iranian Assets (Islamic Republic of Iran v. United States of America). Zie voor de relevante Amerikaanse wetgeving: section 1605 A van de Foreign Sovereign Immunity Act, de Terrorism Risk Insurance Act of 2002, Executive Order 13599.

13. Zie voor het meest geciteerde arrest in dit verband: Duitse Constitutionele Hof (Bundesverfassungsgericht) 14 december 1977, BVerfGE, vol. 46, p. 342,International Law Reports, vol. 65, p. 146.

14. Zie bijvoorbeeld art. 19 sub c UN Convention on Jurisdictional Immunities of States and their Property; A. Reinisch, 'European Court Practice Concerning State Immunity from Enforcement Measures', European Journal of International Law 2006, 17, p. 803-836.

15. Internationaal Gerechtshof, 3 februari 2012, Jurisdictional Immunities of the State (Germany v. Italy), 168 International Law Reports, p. 1-363, ICJ Reports 2012, p. 99, par. 119.

16. Corte Constituzionale 15 juli 1992, n. 329 (Hof stelde dat betalingsbeloften en waarborgen afkomstig van de Nigeriaanse Centrale Bank ten gunste van buitenlandse leveranciers zijn onderworpen aan de Italiaanse jurisdictie). 
ze bestemd zijn voor de uitoefening van soevereine taken. Zo stelde het Zwitserse Federale Hof dat een vreemde Staat in beginsel geen immuniteit van executie geniet wanneer hij geen immuniteit van rechtsmacht geniet, ${ }^{17}$ 'sous la seule réserve que les mesures d'exécution ne concernent pas des biens destinés à l'accomplissement d'acts de souveraineté' [onder het enige voorbehoud dat de executiemaatregelen geen betrekking hebben op goederen bestemd voor de vervulling van soevereine handelingen]. ${ }^{18}$ Hierbij vermeldde het Zwitserse Hof overigens slechts goederen van diplomatieke of consulaire missies. ${ }^{19}$ In ieder geval zal steeds moeten worden nagegaan of die beoogde goederen een soeverein, niet-commercieel doel dienen.

Voorop staat dat goederen die eigendom van de Staat zijn niet ipso facto immuniteit van executie genieten..$^{20}$ Anders gaat men voorbij aan de werkelijkheid dat Staten zich tegenwoordig ook deels gedragen als autonome commerciële actoren die op gelijke voet met private rechtspersonen aan het economisch verkeer deelnemen en een deel van hun goederen aanwenden voor doeleinden die geen soeverein, maar wel een commercieel of privaat karakter hebben. ${ }^{21}$ Men zou bovendien de uitvoerbaarheid van tegen de Staat gewezen vonnissen - waarbij immuniteit van rechtsmacht in een eerdere fase werd verworpen of geen rol speelde -ondermijnen indien men de feitelijke verhaalsmogelijkheden van de schuldeiser al te zeer zou beperken. Slechts wanneer de Staat in het wezen van zijn soevereiniteitsuitoefening wordt geschaad, dient de rechter zich te onthouden van dwangmaatregelen, teneinde de continuïteit van de vervulling van de publieke taken door de Staat te garanderen.

Het is in het licht van deze beginselen dat de overwegingen van de Hoge Raad in de herfstarresten moeten worden begrepen. De vaststelling van de Hoge Raad dat 'Staatseigendommen met een publieke bestemming (...) in elk geval niet vatbaar [zijn] voor gedwongen executie', en dat immuniteit niet geldt indien 'vastgesteld is dat de eigendommen in het bijzonder worden gebruikt of beoogd zijn voor gebruik door de staat voor andere dan niet-commerciële overheidsdoeleinden', bete-

17. Tribunal fédéral suisse 20 juli 1979, République Arabe d'Egypte v. Cinetel International Registered Trust, (1981) Annuaire Suisse de Droit International206, 65 International Law Reports 425, 430.

18. Tribunal fédéral suisse 20 augustus 1998, Banque Bruxelles Lambert (Suisse) SA et al, Arrets du Tribunal Fédéral Suisse 124 III 382 en 389.

19. Ibid.

20. Zie bijvoorbeeld Tribunal Constitucional de España 1 juli 1992, Abbott v. Republic of South Africa, Revista espanola de derecho internacional 1992, vol. 44, p. 565, International Law Reports, vol. 113, p. 414; Bundesverfassungsgericht 14 december 1977, BVerfGE, vol. 46, p. 342, International Law Reports, vol. 65, p. 146) (inclusief de daar geciteerde buitenlandse rechtspraak); Bundesverfassungsgericht 12 april 1983, docket 2 BvR 678/81 e.a.,National Iranian Oil Company, 22 International Legal Materials, p. 1279 (1983), p. 1293, BVerfGE 64, 1

21. In dat verband vindt de term 'government non-commercial purpose', zoals gebruikt in art. 19 sub c van het Verdrag zijn oorsprong in de 1926 Brussels Convention for the Unification of Certain Rules concerning the Immunity of State-owned Ships, dat in art. 2 bepaalde dat schepen die eigendom van de Staat zijn, net als schepen eigendom van private personen, geen immuniteit genieten, tenzij ze voor 'government non-commercial purposes' werden gebruikt. Deze regel is nu neergelegd in art. 16 lid 1 $\mathrm{VN}$-verdrag. kent dus geenszins dat alle goederen van een staat een publieke bestemming hebben en dus immuniteit van executie zouden genieten.

De vraag blijft dan welke goederen in volkenrechtelijke zin, een 'publieke bestemming' of 'sovereign purpose' hebben. Zoals gezegd worden slechts de goederen opgesomd in artikel 21 van het VN-Verdrag als zodanig beschouwd. Voor andere goederen geldt een analyse in concreto, waarbij de schuldeiser aannemelijk dient te maken dat ze niet bestemd zijn voor soevereine doeleinden of geen specifieke bestemming hebben, in welk geval beslag mogelijk is. ${ }^{22}$ Deze standaard van 'aannemelijk maken' dient in het licht van de legitieme rechten en belangen van de schuldeiser te worden uitgelegd, waarover meer in de volgende paragraaf.

\section{Over de op de schuldeiser rustende stelplicht en bewijslast}

In de herfstarresten van 2016 heeft de Hoge Raad gesteld dat de stelplicht en bewijslast met betrekking tot de vatbaarheid voor beslag en executie rust op de schuldeiser die beslag legt of wil laten leggen op goederen van de vreemde staat. Volgens de Hoge Raad zal '[d]e schuldeiser derhalve steeds gegevens moeten aandragen aan de hand waarvan kan worden vastgesteld dat de goederen door de vreemde staat worden gebruikt of zijn bestemd voor, kort gezegd, andere dan publieke doeleinden.'23

Er lijkt evenwel geen internationale regel te bestaan volgens dewelke stelplicht en bewijlast per se op de schuldeiser rusten. Artikel 19 van het VN-Verdrag voorziet daarin in ieder geval niet (expliciet). Ook blijkt een dergelijke regel niet uit de staatspraktijk. Integendeel, sommige buitenlandse rechtspraak verwacht van de vreemde staat ter zake van de bewijsvoering een actieve houding. Zo heeft het Italiaanse Hof van Cassatie beslist dat de bewijslast met betrekking tot de bestemming van de betreffende goederen rust bij de staat die de immuniteit inroept. ${ }^{24}$ Het Hof te Rome besliste dat, in afwezigheid van specifieke oormerking of bestemming van financiële tegoeden, de bewijslast dat deze tegoeden bestemd waren voor publieke doeleinden op de vreemde staat rust. ${ }^{25}$ Het Hof te Milaan maakte duidelijk dat dit volgt uit het beginsel dat de bewijslast rust bij de partij die 'dichter' staat bij het bewijs en in een betere positie is om het bewijs te leveren; er anders over beslissen zou de andere partij (de private schuldeiser) een bewijslast opleggen die onredelijk moeilijk is

22. Zie bijvoorbeeld Schweizerisches Bundesgericht, 10 februari 1960, la cause République Arabe Unie contre dame X (Bundesgerichts 86 I 23), American Journal of International Law (1961), nr. 55, p. 167-171 p. 170 ('In the absence of a precise designation of purpose, attachment is permissible.').

23. HR30 september 2016, ECLI:NL:HR:2016:2236 (Morning Star $t$. Republiek Gabon en Staat der Nederlanden), r.o. 3.5.3. JIN 2016/201 met annotatie van $\mathrm{M}$. Teekens

JOR 2016/353 met annotatie van mr. C.G. van der Plas

JBPR 2017/6 met annotatie van mr. S.S. Leinders

NJB 2016/1839

JWB 2016/352

RvdW 2016/1031

NJ 2017/190

24. Zaken $5888 / 97$ en $2502 / 89.5$

25. Hof Rome 3 juni 2009, Republic of Iraq v. Eurocrediti. 
om aan te voldoen. ${ }^{26}$ Ook in Zwitserland en Oostenrijk is er rechtspraak van de hoogste rechtbanken in die zin. ${ }^{27}$ In Canada hebben verschillende rechtbanken gesteld dat de bewijslast op de vreemde staat rust. Dat is met name het geval omdat immuniteit een uitzondering is op de algemene regel dat de schuldeiser het hele patrimonium van de schuldenaar kan uitwinnen; de vreemde staat zal derhalve moeten bewijzen dat hij recht heeft op dit uitzonderingsregime. ${ }^{28}$ Ook Amerikaanse rechtbanken hebben gesteld dat de bewijslast op de vreemde staat rust indien hij de niet-toepasselijkheid bepleit van de uitzonderingen in de Foreign Sovereign Immunities Act, die de staatsimmuniteit immers beperkt. ${ }^{29}$ Sommige Belgische rechtspraak heeft dan weer de bewijslast verdeeld tussen de schuldeiser en de vreemde staat. ${ }^{30}$

Het is evenwel weinig plausibel dat de Hoge Raad zal terugkomen op zijn beslissing om stelplicht en bewijslast op de schuldeiser te laten rusten. Het lijkt daarom zaak de herfstarresten zo te interpreteren dat ze de bewijsvoering voor de schuldeiser niet onmogelijk maken, bijvoorbeeld ingeval de schuldeiser onvoldoende of zelfs geen toegang heeft tot gege-

26. Hof Milaan 12 maart 2013, Central Bank of Iraq v. Deutsche Bank. Voor een bespreking: LS. Lexjus Sinacta, C. Perrella \&A. Masutti, 'Milan Court of Appeal sheds further light on sovereign immunity'(27 augustus 2013) International Law Office, www.internationallawoffice.com/ Newsletters/Litigation/Italy/LS-Lexjus-Sinacta/Milan-Court-of-Appealsheds-further-light-on-sovereign-immunity (laatst geraadpleegd 21/05/17).

27. Schweizerisches Bundesgericht 24 april 1985, Libyan Arab Socialist People's Jamabiriya v. Actimon SA, International Law Reports, vol. 82, p. 30-36 ('It cannot be stated that the burden of proof rests with the respondent [i.e. de beslaglegger] to establish that the act at issue was performed jure gestionis. In this regard pointers are to be found in the current jurisprudence of the Federal Tribunal, which is based on recognized rules of public international law which have also been adopted in the jurisprudence of other States.'); Oberste Gerichtshof Österreich 11 juli 2012 (3 Ob 18/12m), geciteerd in Graf and Pitkowitz, 'Supreme Court takes restrictive view on state immunity', 27 augustus 2013, International Law Office, 22 november 2012, www.internationallawoffice.com/Newsletters/ Arbitration-ADR/Austria/Graf-Pitkowitz-Rechtsanwlte-GmbH/

Supreme-Court-takes-restrictive-view-on-state-immunitywww. internationallawoffice.com/Newsletters/Arbitration-ADR/Austria/GrafPitkowitz-Rechtsanwlte-GmbH/Supreme-Court-takes-restrictive-view-on -state-immunity, laatst geraadpleegd 21/05/2017.('it was not for the party seeking enforcement to demonstrate that the objects were not immune; rather, this was the responsibility of the foreign state objecting to such enforcement').

28. Republic of Iraq v. Export Development CorporationJ.Q. 2003, nr. 10950, par. 15; Canficorp v. Iraq, Province de Québec, District de Montréal, No. 500-05-009071-935, hoger noot 10, 7 maart 1995, p. 24, 26, dat verwijst naar art. 2803 van de Civil Code van Québec ('A person wishing to assert a right shall prove the facts on which his claim is based.').

29. United States Court of Appeals, 24 juni 1988, Transamerican Steamship Corporation v. Somali Democratic Republic et al, 767 Fed. Supp., 2d series, p. 998-1007, p. 1002 (other citations: 1985 A.M.C. 2617247 U.S. App. D.C. 208); $\diamond$ Same case as next?; United States Court of Appeals, Fifth Circuit, 5 april 1984, Vencedora Oceanica Navigation S.A.v. Compagnie Nationale Algerienne de Navigation (C.N.A.N.) et al, 730 Fed. Supp., 2d series, p. 195-210, p. 199; 1984 A.M.C. 1521; the United States Court of Appeals, Eight Circuit, 22 november 1989, Brewer v. Socialist People's Republic of Iraq et al, 890 Fed. Supp., 2d series, p. 97-105, p. 100 en 101.

30. Hof van Beroep Brussel, 2008/AR/2441, 26 april 2010, M. v. Democratische Republiek Congo, Fortis Bank SA, Belgische Staat, Oxford Reports ILDC 1623 (BE 2010). vens aangaande het gebruik of de bestemming van de betreffende goederen. Anders wordt het beginsel uitgehold dat de vreemde staat geen immuniteit van executie geniet met betrekking tot goederen die worden gebruikt of bestemd zijn voor andere dan publieke doeleinden. De bescherming die het beginsel biedt aan de schuldeiser wordt dan illusoir, en de staatsimmuniteit van executie wordt in de praktijk absoluut.

Hoewel volgens de herfstarresten van de Hoge Raad 'vreemde staten niet gehouden zijn om gegevens aan te dragen waaruit volgt dat hun eigendommen een bestemming hebben die zich tegen beslag en executie verzet', ${ }^{31}$ betekent dit mijns inziens niet dat de rechter uit het stilzwijgen van de vreemde staat geen conclusies kan trekken, zeker wanneer deze staat de mogelijkheid heeft gehad duidelijk te maken dat en waarom de beslagen goederen onder de immuniteit van executie vallen. Uiteindelijk zal, zoals ook volgt uit de herfstarresten, de schuldeiser die beslag legt of wil leggen 'moeten stellen en aannemelijk maken dat en in hoeverre (...) gelden en tegoeden [van de vreemde staat] vatbaar zijn voor beslag en executie'. ${ }^{32}$ Door de standaard van 'aannemelijk maken' te hanteren, vereist de Hoge Raadniet dat de schuldeiser een volledig sluitend bewijs levert van het niet-publieke gebruik of de niet-publieke bestemming van de gelden en tegoeden. De Hoge Raad lijkt zich er kennelijk rekenschap van te geven dat het voor de schuldeiser in de praktijk bijzonder moeilijk is gebruik en bestemming van goederen van een vreemde staat te bewijzen.

De herfstarresten dienen in dit verband te worden geïnterpreteerd in het licht van het recht van de schuldeiser op (a) toegang tot de rechter; en (b) de voldoening van zijn schuldvorderingen.

Wat (a) betreft, valt artikel 6 lid 1 EVRM te citeren, dat het Europees Hof voor de Rechten van de Mens (EHRM) zo heeft geïnterpreteerd dat het het recht van een eiser op een toegang tot de rechter waarborgt. ${ }^{33} \mathrm{Nu}$ heeft de Hoge Raad weliswaar gesteld dat het toekennen van immuniteit van jurisdictie en van executie overeenkomstig internationaal publiekrecht geen schending van artikel 6 EVRM oplevert, ${ }^{34}$ maar dit dictum kan niet zo worden geïnterpreteerd dat het de toegang van de eiser tot de rechter ten enenmale onmogelijk maakt. Veeleer moet worden nagegaan of de beperking van de toegang tot de rechter waartoe de toepassing van de immuniteitsleer aanleiding geeft, in het concrete geval proportioneel is ten opzichte van het nagestreefde doel.Waar respect voor internationale immuniteiten inderdaad een legitiem doel dient, gezien hun rechtsbasis in het internationaal publiekrecht, is de toepassing in concreto van immuniteit niet ipso facto proportioneel. Dat is met name niet het geval wanneer de eiser geen enkel redelijk alternatief heeft om voor zijn rechten op te komen en de door artikel 6 EVRM geboden bescherming derhalve illusoir wordt. De rechterlijke bekrachtiging van de

31. HR 30 september 2016, ECLI:NL:HR:2016:2236 (Morning Star t. Republiek Gabon en Staat der Nederlanden), r.o. 3.5.2.

32. Morning Star, r.o. 3.5.4 [eigen cursivering].

33. Europese Commissie voor de Rechten van de Mens 21 februari 1975, 4451/70, Golder t. het Verenigd Koninkrijk [1975] 1 EHRR 524, [1975] ECHR 1

34. Morning Star, r.o. 3.6.2. 
staatsimmuniteit van executie kan dan gebeurlijk neerkomen op een schending van artikel 6 EVRM en als zodanig aanleiding geven tot aansprakelijkheid van de Nederlandse staat.

Wat (b) betreft, kan met name worden gewezen op het recht op eigendom, neergelegd in artikel 1 van het Eerste Protocol bij het EVRM, dat volgens rechtspraak van het Europees Hof voor de Rechten van de Mens (EHRM) ook omvat de 'peaceful enjoyment of possessions', ${ }^{35}$ met inbegrip van nietlichamelijke bezittingen. Het EHRM heeft verduidelijkt dat eigendom van een schuldvordering, en van een finale en uitvoerbare rechterlijke of arbitrale beslissing onder het recht op eigendom valt. ${ }^{36}$ Schuldeisers hebben derhalve het recht om hun schuldvorderingen op te eisen, ook van vreemde staten. Dit recht impliceert ook het recht op executie ten aanzien van deze staten in geval van niet-betaling.

Hoewel de stabiliteit van de internationale betrekkingen om begrijpelijke redenen tot een beperking van het executierecht van de schuldeiser ten aanzien van vreemde staten noopt, valt een volledig juridisch verbod niet te rijmen met het recht op toegang tot de rechter en het recht op eigendom van de schuldeiser. Dat verklaart waarom een gewoonterechtelijke regel, tevens bekrachtigd door het Internationaal Gerechtshof, ${ }^{37}$ tot stand is gekomen die het de schuldeiser mogelijk maakt beslag te leggen op goederen die niet bestemd zijn voor publieke doeleinden (in volkenrechtelijke zin zoals in paragraaf 1 uiteengezet). Om te voorkomen dat het recht van de schuldeiser illusoir wordt, dient het stelsel van de bewijsvoering zo te worden geregeld dat er kansen bestaan voor de schuldeiser om ook daadwerkelijk beslag te kunnen leggen op dergelijke goederen. ${ }^{38}$ De door de Hoge Raad gehanteerde

35. Europese Commissie voor de Rechten van de Mens, 13 juni 1979 , 6833/74, Marckx t. België, ECLI:NL:XX:1979:AC3090, NJ 1980/462; (1979) 2 EHRR 330, [1979] ECHR 2

36. Europese Commissie voor de Rechten van de Mens 12 oktober 1988 12164/86, Agneesens t. België, 58 Decisions Reports 63.

37. Internationaal Gerechtshof 3 februari 2012, Jurisdictional Immunities of the State (Germany v. Italy), par. 118.

38. Ik werk dit argument, vanuit mensenrechtelijk perspectief, verder uit in C. Ryngaert, 'State Immunity from Execution: Doing Justice to the Financial Interests of Creditors' Leiden International Journal of International Law 2013, afl. 26, p. 73-88. standaard van 'aannemelijk maken' dient mijns inziens in dit licht te worden geïnterpreteerd. ${ }^{39}$

Deze lezing van 'aannemelijk maken' volgt ook uit het hoger gegeven overzicht van buitenlandse rechtspraak. Uit deze rechtspraak blijkt dat de positie van de schuldeiser niet te precair mag worden, dat de vreemde staat geen voordeel mag halen uit zijn stilzwijgen, en dat het restrictieve stelsel van staatsimmuniteit werkbaar moet blijven. Vertaald naar de Nederlandse context na de herfstarresten van de Hoge Raad betekent dit dat, zelfs al rust de stelplicht op de schuldeiser, dan nog van hem niet het onmogelijke mag worden verwacht.

De voorgaande principes betreffende de nuancering van de stelplicht en de bewijslast gelden overigens niet alleen in procedures waarbij de crediteur en de vreemde staat procespartij zijn, maar ook in zaken waarin de vreemde staat niet in rechte verschenen is en zelfs geen procespartij is. Dergelijke procedures zijn in Nederland niet ongebruikelijk in het licht van het deurwaarders-kortgeding met betrekking tot de aanzegging van de minister van Veiligheid en Justitie: in deze procedures is het de Nederlandse staat in plaats van de vreemde staat die partij is. De Nederlandse Staat treedt hier op om zijn volkenrechtelijke verplichtingen ten opzichte van de vreemde staat na te komen. Hij neemt dus de plaats in van de vreemde staat bij het verdedigen van de immuniteit van executie. De legitieme verwachtingen die men inzake stelplicht en bewijslast van de vreemde staat kan koesteren gelden dan ook evenzeer voor de Nederlandse Staat die, al dan niet in overleg met de vreemde staat, zal moeten aangeven waarom de stelling van de schuldeiser inzake de niet-publieke bestemming van de goederen niet aannemelijk zou zijn, en derhalve waarom de goederen niet in aanmerking voor beslag komen.

\section{Over de invulling van het criterium van}

'bestemming' en 'gebruik' van overheidsgoederen

Overeenkomstig de rechtspraak van de Hoge raad moet de schuldeiser aannemelijk maken dat de betreffende schuldvorderingen worden gebruikt of zijn bestemd voor andere dan publieke doeleinden. Nagegaan moet dan worden welke goederen precies voor niet-soevereine doeleinden worden gebruikt of bestemd, en waarop dus beslag mogelijk is. Aangezien de

39. In Morning Star (r.o. 3.6.2) heeft de Hoge Raad beslist dat '[v]olgens vaste rechtspraak van het EHRM ... het toekennen van immuniteit van jurisdictie en van executie overeenkomstig internationaal publiekrecht, geen schending op van art. 6 EVRM [oplevert]'. De Hoge Raad heeft echter geen uitspraak gedaan over de verenigbaarheid van immuniteit van executie met art. 1 van het Eerste Protocol bij het EVRM. Bovendien neemt het vermelde dictum van de Hoge Raad niet weg dat bestaande wetgeving in het licht van art. 6 EVRM, alsook art. 1 Eerste Protocol kan worden geïnterpreteerd. De internationaalrechtelijke techniek van op equity (rechtvaardigheid)gebaseerde interpretatie infra legem van internationale normen - in casu inzake staatsimmuniteit van executie - kan hierbij ook dienstig zijn. Zoals Djeffal stelt: 'Equity infra legem informs the interpreter of international rules how to exercise his or her discretion with notions of justice and fairness.' C. Djeffal, Static and Evolutive Treaty Interpretation: A Functional Reconstruction, Cambridge: Cambridge University Press, 2015, p. 26. Equity vergt dat de legitieme belangen van de schuldeiser voldoende in rekening worden gebracht. Het is onredelijk en onrechtvaardigheid van hem een onmogelijk te leveren bewijs te vragen. 
stelplicht in Nederland op de schuldeiser rust, moet - zoals in paragraaf 2 uiteengezet - de bewijslast werkbaar blijven voor de schuldeiser. De invulling van de standaard van 'bestemming'/'gebruik' moet daarom diens belangen voldoende in rekening brengen.

Voorop staat dat het reduceren van het begrip 'bestemming' tot louter 'uiteindelijke bestemming' onwenselijk is, aangezien overheidseigendommen, met inbegrip van tegoeden uit schuldvorderingen, finaliter steeds aangewend kunnen worden voor overheidsdoeleinden die als 'publiek' kunnen worden beschouwd. In deze interpretatie zou de vreemde staat steeds immuniteit van executie genieten.

Het is voor de schuldeiser bovendien nagenoeg onmogelijk inzicht te krijgen in de geldstromen tussen overheidsentiteiten die via commerciële contracten opbrengsten voor de staat genereren, een klassiek scenario in executieprocedures. Zelfs indien de schuldeiser daarin slaagt, en enig inzicht verwerft in de begroting van de staat, met inbegrip van de eventueel nietpublieke besteding van overheidsmiddelen, zal het hem opnieuw bijna onmogelijk zijn het verband te leggen tussen de specifieke schuldvordering en de uiteindelijke niet-publieke besteding van de opbrengst, voor zover überhaupt sprake kan zijn van niet-publieke begrotingsposten.

Om het bestemmingscriterium werkbaar te houden hoeft de schuldeiser daarom niet aannemelijk te maken dat de ultieme bestemming niet-publiek is, maar slechts dat de onmiddellijke bestemming van het goed (bijvoorbeeld een schuldvordering) of het gebruik van de opbrengsten daarvan niet-publiek is. Dit criterium wordt ook gehanteerd in buitenlandse rechtspraak.

Een Canadese rechtbank heeft bijvoorbeeld geoordeeld dat zelfs indien een deel van de opbrengst van een schuldvordering (in dat geval een huurvordering) wordt aangewend voor belastingdoeleinden, dit niet tot gevolg heeft dat de commerciële bestemming van een beleggingsconstructie (in dat geval verhuur van gebouwen) wordt aangetast. ${ }^{40}$ En zelfs indien de oorspronkelijke opzet van zo'n constructie publiek was, kan het daaropvolgende gebruik ervan commercieel zijn, en kunnen de betrokken eigendommen dus in aanmerking komen voor beslag. ${ }^{41}$ Ook het aanhouden van een zichtrekening of het sluiten van een safekeeping agreement met een bank werd als commercieel beschouwd, 'since it contemplates deposits and drawings and other transactions that are by definition commercial in nature'. ${ }^{42}$ Een en ander wijst erop dat voor Canadese rechtbanken de onmiddellijke aanwending van de staatseigendom determinerend is: wanneer deze aanwending niet-publiek is (commercieel) geniet de vreemde staat geen

40. Lab Chrysotile inc. v. Rasheed Bank, Court of Appeal of Quebec, 23 december 2002, [2003] Recueil de Jurisprudence du Quebec 553.

41. Kuwait Airways Corp. v. Iraq [2010] S.C.J. No. 40, par. 35 ('The original appropriation of the aircraft was a sovereign act, but the subsequent retention and use of the aircraft by IAC were commercial acts.') (in de context van een staatsonderneming - IAC - waaraan de staat Irak initieel vliegtuigen had toebedeeld).

42. Canficorp v. Iraq, Province de Québec, District de Montréal, No. 500-05-009071-935, 7 maart 1995, hoger noot 10, p. 17-18. immuniteit van executie met betrekking tot de eigendom in kwestie.

In Engelse rechtspraak wordt een vergelijkbaar criterium gehanteerd. Met name Orascom Telecom Holding SAE v. Republic of Chad and another (Citibank NA, third party) (International Bank for Reconstruction and Development intervening), een Engelse zaak (High Court) uit 2008, kan worden vermeld. In Orascom besliste rechter Michael Burton dat een bankrekening (bij een derdebeslagene) geen immuniteit genoot omdat deze 'was being operated for the purpose of a commercial transaction', ook al was het doel van de transactie het begunstigen van de staat. Rechter Burton stelde dat de

'account was established, and has been operated, for the purposes of a commercial transaction, namely (i) so as to receive the proceeds of a contract for the supply of goods or services; and/or (ii) so as to be part of a system specifically established for the purposes of (repayment of) loans by the World Bank to Chad'. ${ }^{43}$

In deze zaak keek de rechter dus naar de manier waarop de staat de tegoeden heeft gegenereerd en aanwendt, ook al heeft de set-up van de financiële constructie een soevereine doelstelling. Deze benadering, zoals die ook in Canada wordt gebruikt, kan als de 'origin approach' worden aangemerkt. In de later zaakServaas hanteerde Lord Clarke het concept 'current use ${ }^{34}$ als een compromis tussen 'origin' en 'ultimate purpose'. Uiteindelijk is de Servaas-standaard echtermogelijk niet zo verschillend van de Orascom-standaard. In dit verband heeft Reece Thomas het volgende opgemerkt:

'These issues are clearly highly technical and one wonders what would happen in a case where monies generated by commercial transactions were simply going to be transferred back for use by the foreign state. Without the rescheduling dimension would that be use for a "non-commercial purpose" while held in the UK? The problem is whether it is correct to distinguish current use from origin in the absence of real evidence as to current use. ${ }^{35}$

De 'current use' en de 'origin' benadering lijken dus overlap te vertonen, maar wat cruciaal is, is dat de rechter niet naar de verdere bestemming van de goederen kijkt.

43. Orascom Telecom Holding SAE v. Chad ((Citibank NA, third party) (International Bank for Reconstruction and Development intervening) [2008] England and Wales High Court 1841 (Commercial Court); [2009] 1 All England Law Reports (Comm) 135, par. 23-24; [2008] 2 Lloyd's Reports 396; [2008] 2 Commercial Law Cases 296.

44. UK Supreme Court, 17 August 2012, SerVaas Inc v. Rafidain Bank, [2012] UK Supreme Court 40; [2013] 1 Appeal Cases 595, p. 612, par. 32 (per Lord Clarke) ('The determinative feature, in my view, is the absence of any current or future commercial activity on the part of Iraq.'). Ook te vinden in [2012] 3 Weekly Law Reports 545; [2012] 4 All England Law Reports 1081.

45. K. Reece Thomas, 'Enforcing against state assets: the case for restricting private creditor enforcement and how judges in England have used "context" when applying the "commercial purposes" test', Journal of International and Comparative Law 2015, afl. 2(1) p.1-31. 
Ook niet-Angelsaksische rechtspraak is deze benadering genegen. Zo is er een uitspraak uit 2011 van het Zweedse Hooggerechtshof die stelde dat een eigendom van de Russische Federatie op het moment van het verzoek niet substantieel voor officiële doeleinden werd gebruikt, en dat potentieel toekomstig gebruik niet relevant was. ${ }^{46} \mathrm{Er}$ is ook een erg relevant precedent van het Franse Hof van Cassatie uit 2005 dat executie tegen een staatseigendom toestond op grond van de omstandigheid dat er een commerciële verhouding bestond tussen de staat en de private partij; staatseigendom die in deze verhouding werd verworven, werd geacht een niet-soevereine bestemming te hebben. ${ }^{47}$

Uit de geciteerde rechtspraak kan worden opgemakt dat geen immuniteit van executie toekomt aan schuldvorderingen die tot stand kwamen in het kader van een gebruikelijke beheersoperatie waarop het privaatrecht van toepassing is, en waarvan de tegoeden meteenworden aangewend voor investeringen en betalingen binnen een gesloten contractueel systeem van commerciële aard. De betrokken vorderingen zijn dan beslagbaar via derdenbeslag en de staatsimmuniteit van executie is niet van toepassing.

Overigens objectiveert en vereenvoudigt een standaard die de nadruk legt op de aard van een transactie of constructie, of althans de onmiddellijke bestemming van de opbrengsten hieruit, de immuniteitsanalyse. Dat geldt niet in de laatste plaats voor de oordelende rechtbank. Deze standaard vermijdt immers dat de rechter uitspraken moet doen over de uiteindelijke politieke motieven en de doelstellingen die de vreemde overheid met de opbrengst wil verwezenlijken. ${ }^{48}$

\section{Over de tenuitvoerlegging van arbitrale vonnissen gewezen tegen staten}

In paragrafen 1 en 2 heb ik uiteengezet hoe de rechtbank de stelplicht en het bestemmingscriterium dient toe te passen en

46. Högsta Domstolens Beslut [Supreme Court Decision] Ö170-10 (2011), r.o. 20 en 23. De eigendom in kwestie werd vooral gebruikt voor het onderdak bieden aan niet-diplomatiek personeel.

47. Cour de Cassation, Chambre civile 1, 25 januari 2005, 03-18.176, Bulletin $2005 \mathrm{I} \mathrm{N}^{\circ} 39$ p. 31 . Net als in de eerder aangehaalde Engelse Orascomzaak vervaagt hierbij dus de grens tussen de bestemming van het goed en de aard van de handeling. Het Hof overweegt het volgende met betrekking tot de lasten die de Staat Congo moest betalen aan de vereniging van mede-eigenaren van een gebouw in Frankrijk (een betaling waartoe de Staat was veroordeeld): 'Que l'acquisition par l'Etat du Congo de biens immobiliers en France, fussent-ils affectés au logement de son personnel diplomatique, ne constitue pas une prérogative ou un acte de souveraineté mais seulement une opération habituelle de gestion relevant du droit privé ; qu'ayant constaté que les biens en cause n'étaient pas affectés aux services de l'Ambassade ou de ses annexes et n'étaient pas la résidence de l'ambassadeur, puis retenu que cette acquisition impliquait pour l'Etat du Congo le paiement des charges de copropriété de sorte que la créance du syndicat se rattachait à cette opération, la cour d'appel a, à bon droit, décidé que la République démocratique du Congo ne pouvait pas opposer son immunité d'exécution.' De redenering gaat als volgt: (1) het verwerven van onroerend goed is geen soevereine handeling, maar 'une opération habituelle de gestion relevant du droit privé; (2) het betalen van lasten aan de vereniging van mede-eigenaren is nauw verbonden met deze verwerving; (3) bijgevolg kan de staat de immuniteit van executie niet inroepen tegen de schuldvordering van de vereniging.

48. M.L. Jewett \&H.L. Molot, 'State Immunity Act - Basic Principles', Canada Law Review 1983, afl. 61, p. 843, p. 846-847. er vorm aan dient te geven in generieke executiezaken. Een bijzondere categorie van zaken betreft evenwel de tenuitvoerlegging van een tegen een staat gewezen arbitraal vonnis in plaats van een regulier gerechtelijk vonnis (een vonnis van een statelijke rechtbank). Tot nu toe heeft de Hoge Raad geen onderscheid tussen deze soorten vonnissen gemaakt, maar het verdient aanbeveling dat hij dit toch doet, gezien de op instemming van de partijen gebaseerde voorafgaande arbitrageprocedure.

In executiezaken tegen vreemde staten kan het voorkomen dat in de 'bodemzaak' een doorgaans buitenlands scheidsgerecht een bedrag heeft toegewezen aan de schuldeiser, bijvoorbeeld in een procedure op basis van het arbitragereglement van de International Chamber of Commerce (ICC). Met het oog op executie initieert de schuldeiser vervolgens procedures in één of meer staten, wier rechtbankenexequatur kunnen verlenen op het arbitrale vonnis. Een en ander vindt zijn grondslag in het Verdrag van New York over de Erkenning en Tenuitvoerlegging van Arbitrale Vonnissen (1958). ${ }^{49}$ Gesteld kan worden dat staten die zich onderwerpen aan de ICC-regels en het Verdrag van New York impliciet afstand doen van hun immuniteit van executie.

Onder het Verdrag van New York kan de tenuitvoerlegging van een arbitraal vonnis slechts in een beperkt aantal gevallen geweigerd worden. Het Verdrag vermeldt staatsimmuniteit daarbij niet. Bovendien bepaalt artikel 35 lid 6 van de ICC-regels:

'Every award shall be binding on the parties. By submitting the dispute to arbitration under these Rules, the parties undertake to carry out any Award without delay and shall be deemed to have waived their right to any form of recourse insofar as such waiver can validly be made.'

Dezelfde tekst kan ook worden aangetroffen in eerdere versies van de ICC-regels. ${ }^{50}$ Hieruit kan worden afgeleid dat de staat, door zijn toevlucht te nemen tot arbitrage op basis van de ICC-regels in een staat die partij is bij het Verdrag van New York, impliciet afstand heeft gedaan van zijn recht om immuniteit, met inbegrip van immuniteit van executie, in te roepen. Zo besliste het Franse Hof van Cassatie in Creighton Ltd $t$. Qatar dat de staat Qatar, door erin toe te stemmen geschillen aan ICC-arbitrage voor te leggen, zich voorneemt een arbitraal vonnis onverwijld ten uitvoer te leggen en daarmee afstand van de immuniteit van executie deed. ${ }^{51}$ Dit element van voorafgaande toestemming onderscheidt vonnissen van arbitrale rechtbanken van vonnissen van nationale rechtbanken. Waar op deze laatste de gewoonterechtelijke regels van immuniteit van executie onverkort van toepassing zijn, kunnen vonnissen

49. Het is daarbij niet relevant dat de vreemde staat zelf partij is bij het Verdrag. Relevant is slechts dat het vonnis in een verdragsstaat is gewezen en ten uitvoer wordt gelegd in een andere verdragsstaat. ICC-arbitrages vinden vaak plaats in Frankrijk (Parijs), dat partij is bij het Verdrag. Nederland is ook partij bij het Verdrag.

50. In de versie van 1998 gaat het om art. 28 lid 6, en in de versie van 1975 om art. 24 .

51. Hof van Cassatie (Frankrijk), chambre civile 1, 6 juli 2006. 
van arbitrale scheidsgerechten in principe ten uitvoer worden gelegd in andere staten (partijen bij het Verdrag van New York) zonder dat de staat de immuniteit van executie kan inroepen. Lady Fox, een van de grote autoriteiten op het vlak van de staatsimmuniteit, ${ }^{52}$ heeft bijvoorbeeld de gelijkstelling van de afdwinging van nationale rechterlijke uitspraken en arbitrale uitspraken als volgt bekritiseerd:

'I would challenge [the] subordination of enforcement ofarbitral awards to the same regime as applies to foreign judgments of national courts, at leastin respect of awards that are confined to commercial relationships and do not awardcompensation for regulatory failings of the State. ${ }^{53}$

Een gelijkstelling van arbitrale en traditionele vonnissen wat betreft immuniteit van executie gaat voorbij aan de integriteit van de op partijautonomie gebaseerde internationale handelsarbitrage, en in het bijzonder de commerciële belangen die daar spelen. ${ }^{54}$ Wanneer een staat instemt met arbitrage heeft hij bijgevolg ook ingestemd met de mogelijke gevolgen van een dergelijke arbitrage, met name een tegen hem gewezen vonnis en de tenuitvoerlegging daarvan. Aan een dergelijke staat dient dan ook geen immuniteit van executie toe te komen.

\section{Conclusie}

Overeenkomstig de rechtspraak van de Hoge Raad dient de schuldeiser aannemelijk te maken dat de betreffende schuldvorderingen worden gebruikt of zijn bestemd voor andere dan publieke doeleinden. Zelfs al rust de stelplicht ter zake op de schuldeiser, dan kan van hem het onmogelijke niet worden gevergd. De bescherming die het systeem van beperkte staatsimmuniteit van executie aan de schuldeiser biedt, mag immers niet illusoir worden. Het volstaat daarom dat de schuldeiser voldoende informatie aanreikt waaruit kan worden afgeleid dat de onmiddellijke bestemming of het onmiddellijke gebruik van (de opbrengsten van) de vordering niet-publiek van aard zijn. Ten slotte zij erop gewezen dat de gewoonterechtelijke regels inzake staatsimmuniteit niet gelden in deze procedure, die de tenuitvoerlegging van een arbitraal vonnis betreft. Door met arbitrage in te stemmen heeft de staat immers impliciet afstand van zijn immuniteit van executie gedaan. Deze analyse 'in context' brengt met zich mee dat de herfstarresten van de Hoge Raad (2016), hoewel ze op het eerste gezicht restrictief lijken en de belangen van de vreemde staat voor het voetlicht brengen, de deur niet definitief sluiten voor schuldeisers die executiemaatregelen tegen eigendommen van vreemde staten beogen te nemen.

52. H. Fox \& P. Webb, The Law of State Immunity, Oxford: Oxford University Press 2013.

53. H. Fox, 'State Immunity and the New York Convention', in: E. Gaillard \& D. di Pietro (red.), Enforcement of Arbitration Agreements and International Arbitral Awards: The New York Convention in Practice, Cameron May 2008, p. 829-864, p. 861.

54. R. Sharma, 'Enforcement of Arbitral Awards and Defence of Sovereignty: The Crouching Tiger and the Hidden Dragon', Lapland Law Review 2011, afl. 1, p. 252-264, p. 263. 